\title{
Perbandingan Mother Wavelet dalam Proses Denoising pada Suara
}

\author{
Rahmat Ramadhan*1, Agfianto Eko Putra ${ }^{2}$ \\ ${ }^{1}$ Jurusan Teknik Informatika, F.Teknik, Unhalu, Kendari \\ ${ }^{2}$ Jurusan Ilmu Komputer dan Elektronika, FMIPA UGM, Yogyakarta \\ e-mail: *11 f1a107041@gmail.com, ${ }^{2}$ agfi68@ gmail.com
}

\begin{abstract}
Abstrak
Transformasi Wavelet telah digunakan dalam proses denoising pada suara dengan tujuan untuk meningkatkan kualitas dari rekaman suara yang tercampur dengan derau. Jenisjenis derau yang terlibat antara lain White Gaussian Noise (WGN), White Uniform Noise (WUN) dan Colored Noise. Dalam penelitian ini dilakukan perbandingan terhadap beberapa mother wavelet, diantaranya Daubechies, Coiflet dan Symlet, dalam proses denoising pada sinyal suara yang diberikan WGN, WUN dan Colored Noise. Metode thresholding yang digunakan dalam proses denoising adalah Soft Thresholding dan nilai threshold berupa TimeAdapted Threshold (TAT) yang diperoleh dengan melakukan estimasi energi untuk membangun sinyal melalui Teager Energy Operator (TEO). Pengujian untuk mendapatkan mother wavelet terbaik dilakukan menggunakan uji Kruskal-Wallis yang dilanjutkan dengan uji Mann-Whitney. Hasil yang diperoleh menunjukkan bahwa Db20, Db30, Db40 dan Coif5 merupakan mother wavelet yang baik untuk mereduksi WGN; Db40, Db20 dan Db30 merupakan mother wavelet yang baik untuk mereduksi WUN dan untuk mereduksi Colored Noise, dapat menggunakan beberapa mother wavelet dalam penelitian ini, kecuali Db30 dan Db40.
\end{abstract}

Kata kunci-Mother wavelet, denoising, sinyal suara, TAT, Soft Thresholding.

\begin{abstract}
Wavelet Transform was used in denoising process on speech to enhance the quality of speech that courrupted by noise. The kinds of involved noises are White Gaussian Noise (WGN), White Uniform Noise (WUN) and Colored Noise. In this research, the comparison of mother wavelet is performed among Daubechies, Coiflet and Symlet, in denoising process on speech which given by WGN, WUN and Colored Noise. The thresholding method is used in denoising process is Soft Thresholding and threshold value is Time Adapted Threshold (TAT) which obtained by estimating the power for building the signal through Teager Energy Operator (TEO). The testing for obtaining the best moher wavelet is using Kruskal-Wallis test and followed by Mann-Whitney test. The result shows that Db20, Db30, Db40 and Coif5 mother wavelets are better than others to reduce WGN; Db40, Db20 dan Db30 mother wavelets are better then the other to reduce WUN and to reduce Colored Noise can use some mother wavelets in this research, except Db30 and Db40.
\end{abstract}

Keywords-Mother wavelet, denoising, speech signal, TAT, Soft Thresholding

\section{PENDAHULUAN}

$\mathrm{T}$ ransformasi Wavelet telah dikembangkan pada berbagai bidang ilmu diantaranya bidang medik, geofisika, fluida, matematika, fisika, pemrosesan citra digital, pemrosesan sinyal digital, analisa numerik dan lain sebagainya [1]. Penggunaan Transformasi Wavelet dalam 
pemrosesan sinyal digital adalah dalam proses denoising pada suara. Proses denoising dilakukan karena proses perekaman suara tidak selalu terjadi pada lingkungan atau daerah yang bebas dari derau (noise). Hal ini menyebabkan derau dapat ikut terekam sehingga tersimpan dalam sinyal rekaman suara. Keberadaan derau tentunya dapat menyebabkan menurunnya kualitas sinyal suara sehingga dapat menyebabkan terjadinya kesalahan interpretasi misalnya dalam sistem pengenalan suara. Oleh karena itu, proses reduksi derau (denoising) dibutuhkan untuk mengatasi terjadinya kesalahan interpretasi.

Pemilihan Transformasi Wavelet sebagai salah satu alat yang digunakan pada proses denoising pada suara karena Transformasi Wavelet baik digunakan pada sinyal non-stasioner saat mendeteksi kejadian-kejadian. Transformasi Wavelet memiliki keunggulan diantaranya dapat memberikan informasi berupa frekuensi dan waktu suatu kejadian, dapat melakukan analisis multiresolusi yaitu menganalisis sinyal dalam frekuensi dan resolusi yang berbeda. Hal tersebut yang membedakannya dengan Transformasi Fourier karena hanya dapat memberikan informasi berupa frekuensi kejadian [2].

Terdapat beberapa jenis derau yang diketahui yang dapat ikut terekam ketika proses perekaman suara diantaranya White Gaussian Noise (WGN), White Uniform Noise (WUN) [3] dan Colored Noise [4] yang memiliki pola sinyal yang berbeda-beda. Untuk memisahkan antara derau dan suara, dilakukan ekstraksi (dekomposisi) pada suara berderau melalui Decimated Wavelet Transform (DWT) ke dalam subband yang berbeda-beda dengan menggunakan mother wavelet sebagai filter. Proses denoising kemudian dilakukan pada masing-masing subband dengan menggunakan metode thresholding sebelum dilakukan proses rekonstruksi, sehingga diperoleh suara dengan derau yang telah direduksi. Penggunaan mother wavelet yang tepat akan akan memberikan hasil yang baik untuk sinyal suara hasil denoising.

Penelitian tentang proses denoising pada sinyal suara telah banyak dilakukan oleh para peneliti sebelumnya. Penelitian dalam proses denoising pada suara terus berkembang seiring dengan adanya keinginan untuk memperoleh hasil yang memuaskan. [4] dalam penelitiannya mengusulkan penggunaan threshold yang berbeda untuk masing-masing subband wavelet. Dalam penelitian tersebut juga mengusulkan tiga prosedur yang akan digunakan dalam proses denoising yaitu deteksi jeda, estimasi profil derau dan pengkategorian bagian suara atau tanpa suara. Dilakukan pula modifikasi terhadap metode Hard Thresholding untuk proses thresholding. Dalam penelitian lain yang dilakukan oleh [5], mereka menggunakan sistem perbaikan kualitas suara berbasis wavelet denoising melalui estimasi Adaptive Time-Frequency Threshold (ATFT), dimana untuk tahap awal pada sistem dilakukan pemrosesan awal (preprocessing) pada suara berderau dengan tujuan untuk menginisialisasi tingkatan derau yang lebih rendah dari suara berderau. Algoritma Pengurangan Spektral Derau Tergeneralisasi kemudian diimplementasikan untuk memberikan nilai awal yang lebih rendah pada tingkatan derau. Untuk mendekomposisi sinyal suara hasil preprocessing, digunakan mother wavelet dari keluarga wavelet Daubechies melalui Wavelet Packet Transform (WPT).

Hal yang berbeda dilakukan oleh [3] yaitu melakukan perbandingan terhadap tiga teknik threshold yaitu Universal, SURE Shrink dan Bayes Shrink Threshold dalam proses denoising pada citra. Hasil pengujian menunjukkan bahwa SURE Shrink dan Bayes Shrink Threshold memberikan hasil lebih baik dibandingkan dengan Universal Threshold, namun Bayes Shrink Threshold lebih unggul dalam hal komputasi. Untuk proses denoising pada suara, dilakukan melalui WPT dan menggunakan mother wavelet Daubechies 40 sebagai filter. Bayes Shrink Threshold kemudian dikombinasikan dengan Time-Addapted Threshold (TAT) sebagai nilai threshold yang digunakan. Penelitian yang dilakukan oleh [6] juga menerapkan hal yang berbeda dalam proses denoising yaitu menggabungkan antara teknik Envelope dan WPT. Untuk nilai threshold, mereka menggunakan Universal Threshold yang kemudian diaplikasikan pada WPT melalui koefisien Envelope.

Kemudian [7], menerapkan Transformasi Wavelet sebagai preprocessing dalam sistem temu kembali pada lagu berbasis isi. Dalam melakukan thresholding, digunakan Adaptive Wavelet Soft Threshold pada audio dimana keakuratan hasil dari sistem temu kembali bergantung pada koefisien wavelet TEO dan faktor peningkat.

IJCCS Vol. 8, No. 1, January 2014: 69-80 


\section{METODE PENELITIAN}

Perbandingan mother wavelet dalam proses denoising pada suara yang diberikan derau WGN, WUN dan Colored Noise dilakukan untuk memperoleh mother wavelet terbaik terhadap masing-masing jenis derau yang diberikan. Adapun langkah-langkah penentuan mother wavelet terbaik yaitu :

1. Melakukan proses denoising pada sinyal suara yang diberikan satu jenis derau misalnya WGN, WUN atau Colored Noise.

2. Menghitung nilai MSE untuk suara hasil denoising pada langkah ke-1 untuk sebuah mother wavelet menggunakan persamaan (1) dimana $\hat{S}$ menyatakan sinyal suara hasil denoising dan $S$ menyatakan sinyal suara tanpa derau.

$$
M S E=\frac{1}{n}\left(\sum_{i=1}^{n}\left(\hat{s}_{i}-s_{i}\right)^{2}\right) ; \hat{S}=\left(\hat{s}_{1}, \hat{s}_{2}, \ldots, \hat{s}_{n}\right), S=\left(s_{1}, s_{2}, \ldots, s_{n}\right)
$$

3. Mengulangi langkah ke-1 dan ke-2 sebanyak 10 kali dengan menggunakan mother wavelet dan jenis derau yang sama. Langkah ke-3 ini menghasilkan sampel acak berupa nilai MSE hasil denoising dari tiap mother wavelet untuk tiap jenis derau yang dihasilkan, yang berukuran $n=10$. Tiap sampel acak kemudian ditentukan rata-rata $\bar{X}_{i}$ dan strandar deviasi $S^{2}$ untuk nilai MSE.

4. Pengujian nilai MSE sinyal suara hasil denoising untuk penentuan mother wavelet terbaik. Mother wavelet terbaik diasumsikan sebagai mother wavelet yang ketika digunakan dalam proses denoising, dapat menghasilkan nilai MSE terkecil. Penentuan mother wavelet terbaik dilakukan melalui pengujian hipotesis statistik.

Gambaran umum proses denoising menggunakan DWT pada suara yang diberikan derau adalah seperti pada Gambar 1.

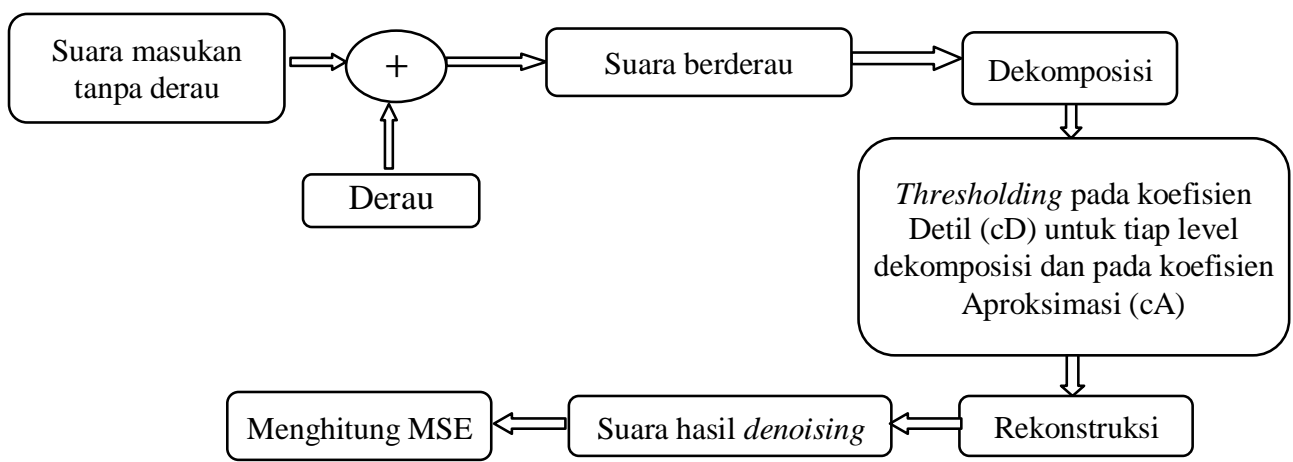

Gambar 1 Gambaran umum proses denoising untuk sinyal suara yang diberikan berbagai jenis derau

Prosedur untuk melakukan proses denoising adalah sebagai berikut :

1. Memasukan sinyal suara tanpa derau.

2. Menambahkan derau pada sinyal suara masukan.

3. Melakukan dekomposisi pada sinyal suara berderau.

4. Melakukan proses thresholding pada tiap subband hasil dekomposisi menggunakan metode thresholding jenis Soft Thresholding, dengan nilai threshold berupa Time Adapted Threshold (TAT).

5. Merekonstruksi sinyal hasil thresholding.

Untuk melakukan proses thresholding pada suara berderau, diasumsikan bahwa misalkan $t=1,2 \ldots n$, suatu sinyal berderau $y(t)$ merupakan jumlahan dari sinyal tanpa derau $x(t)$ dan derau $n(t)$ yang dinyatakan oleh persamaan (2). 


$$
y(t)=x(t)+n(t) ; t=1,2, \ldots, n
$$

Dalam domain Transformasi Wavelet diperoleh

$$
Y_{j, k}=X_{j, k}+N_{j, k} \quad ; k=1,2, \ldots m_{j} ; j=1,2, \ldots, \text { level }
$$

dimana $Y_{j, k}, X_{j, k}$ dan $N_{j, k}$ berturut-turut menyatakan nilai koefisien wavelet ke - $k$ pada level dekomposisi ke - $j$ untuk sinyal suara berderau, sinyal suara tanpa derau dan sinyal derau, yang diperoleh melalui Transformasi Wavelet.

Metode thresholding yang digunakan untuk proses denoising dalam penelitian ini adalah Soft Thresholding yang dinyatakan oleh persamaan (4).

$$
T_{s}\left(Y_{j, k}, \lambda_{j}\right)= \begin{cases}\operatorname{sgn}\left(Y_{j, k}\right)\left(\left|Y_{j, k}\right|-\lambda_{j}\right) & ; j i k a\left|Y_{j, k}\right|>\lambda_{j} \\ 0 & ; j i k a\left|Y_{j, k}\right| \leq \lambda_{j}\end{cases}
$$

dimana $Y_{j, k}$ menyatakan koefisien wavelet ke $-k$ pada level dekomposisi ke $-j$ dan $\lambda_{j}$ adalah nilai threshold pada level dekomposisi ke $-j$ [3]. Nilai threshold $\lambda_{j}$ pada masing-masing level dekomposisi yang digunakan adalah Time Adapated Threshold (TAT) yaitu nilai threshold yang dapat beradaptasi dengan bagian suara dan bagian derau pada sinyal suara. Ketika berada pada bagian suara, maka nilai TAT akan menjadi lebih kecil, sebaliknya ketika berada pada bagian derau, maka nilai threshold akan menjadi lebih besar.

Dalam penentuan nilai threshold, terlebih dahulu dilakukan estimasi nilai standar deviasi derau $\hat{\sigma}_{j}$ pada masing-masing level dekomposisi dimana

$$
\hat{\sigma}_{j}=\frac{\operatorname{Median}\left(\left|Y_{j}\right|\right)}{0.6745} ; j=1,2, \ldots, \text { level }
$$

Dalam menggunakan TAT, digunakan juga Bayes Shrink Threshold $\lambda_{j}^{\text {Bayes }}$ yang dinyatakan oleh persamaan (6)

$$
\lambda_{j}^{\text {Bayes }}=\frac{\hat{\sigma}_{j}^{2}}{\hat{\sigma}_{X_{j}}} ; j=1,2, \ldots, \text { level }
$$

dimana $\hat{\sigma}_{X_{j}}$ menyatakan estimasi standar deviasi dari sinyal tanpa derau pada subband level ke $-j$. Nilai $\hat{\sigma}_{X_{j}}$ dinyatakan oleh

$$
\hat{\sigma}_{X_{j}}=\sqrt{\max \left({\sigma_{Y_{j}}}^{2}-\hat{\sigma}_{j}^{2}, 0\right)} ; j=1,2, \ldots, \text { level }
$$

dimana ${\sigma_{Y}}^{2}$ merupakan ragam dari koefisien wavelet pada masing-masing subband level ke - $j$. Jika ${\sigma_{Y_{j}}}^{2} \leq{\hat{\sigma}_{j}}^{2}$ maka nilai seluruh koefisien wavelet pada subband level ke - $j$ adalah nol, dalam hal ini bahwa nilai threshold pada subband level ke $-j$ adalah takhingga.

Estimasi energi yang dibutuhkan dalam membangun sinyal, diperlukan untuk menghasilkan TAT. Sebuah metode yang dapat digunakan yaitu Teager Energy Operator (TEO) yang dinyatakan oleh persamaan (8).

$$
\begin{gathered}
T E O_{j, k}=Y_{j, b}^{2}-Y_{j, b-1} \cdot Y_{j, b+1} ; \\
j=1,2, \ldots, \text { level } ; b=2,3, \ldots,\left(m_{j}-1\right) ; k=1,2, \ldots,\left(m_{j}-2\right)
\end{gathered}
$$

Koefisien TEO dapat memberikan estimasi energi yang dibutuhkan dalam membangun sinyal. Untuk mengurangi sensitivitas terhadap derau maka dibutuhkan suatu TEO yang halus (smooth TEO) sehingga [8] mengusulkan untuk mengkonvolusi TEO dengan sebuah Hamming window $H_{j}(i)$ yang dinyatakan oleh persamaan (9)

$$
\begin{gathered}
M_{j, l}=\sum_{i=0}^{N} T E O_{j,(k-i)} * H_{j}(i) ; \\
H_{j}(i)=0,54-0,46 \cos \left(\frac{2 \pi i}{N}\right) ; N=\frac{256}{2^{j}}-1 ; \\
j=1,2, \ldots, \text { level } ; k=1,2, \ldots, W ; W=\left(m_{j}-2\right) ; l=1,2, \ldots,(N+W-1)
\end{gathered}
$$

dimana $j$ menyatakan level dekomposisi ke $-j$ dari DWT.

IJCCS Vol. 8, No. 1, January $2014: 69-80$ 
Proses normalisasi kemudian dilakukan untuk menghasilkan nilai threshold yang dapat beradaptasi dengan bagian suara dan tanpa suara, yaitu dengan membagi seluruh koefisien smooth TEO dengan koefisien maksimum smooth TEO pada masing-masing subband, yang dinyatakan oleh persamaan (10).

$$
M_{j, l}^{\prime}=\frac{M_{j, l}}{\max \left(M_{j}\right)} ; j=1,2, \ldots, \text { level } ; l=1,2, \ldots,(N+W-1)
$$

M.Bahoura dan J.Routa [9], kemudian mengusulkan suatu TAT untuk menghasilkan nilai threshold yang dapat beradaptasi dengan bagian suara dan tanpa suara yaitu

$$
\lambda_{j, l}=\lambda_{j}\left(1-M_{j, l}^{\prime}\right) ; j=1,2, \ldots, \text { level } ; l=1,2, \ldots,(N+W-1)
$$

dimana

$$
\lambda_{j}=\lambda_{j}^{\text {Bayes }}
$$

Mother wavelet terbaik ditentukan berdasarkan nilai MSE yang dihasilkan. Dalam penelitian ini, diambil sampel acak berupa nilai MSE hasil denoising, dimana proses denoising dilakukan sebanyak 10 kali dengan menggunakan mother wavelet dan derau yang sama. Berdasarkan sampel acak yang diperoleh, dilakukan pengujian untuk menentukan mother wavelet terbaik yaitu menggunakan uji Kruskal-Wallis yang dilanjutkan dengan uji MannWhitney. Statistik uji untuk uji Kruskal-Wllis adalah seperti pada persamaan (13)

$$
h=\frac{12}{N(N+1)} \sum_{i=1}^{k} \frac{r_{i}^{2}}{n_{i}}-3(N+1)
$$

dimana $n_{i}$ adalah ukuran sampel ke $-i, r_{i}$ adalah jumlah peringkat sample ke $-i, k$ adalah banyaknya sampel acak dan $N=\sum_{i=1}^{k} n_{i}$. Perumusan uji hipoteisis untuk uji Kruskal-Wallis dinyatakan oleh

$$
\begin{gathered}
H_{0} \text { : Setiap sampel berasal dari populasi yang sama } \\
H_{1}: \text { Minimal terdapat satu sampel berasal dari populasi yang berbeda }
\end{gathered}
$$

dan wilayah kritik untuk penolakan $H_{0}$ terjadi ketika nilai $h>\chi_{\alpha}^{2}(d f) ; d f=k-1$ [10].

Untuk $k$ sampel yang telah diuji, nantinya akan diperoleh rata-rata peringkat $\bar{r}_{i}$ untuk masing-masing sampel dimana

$$
\bar{r}_{i}=\frac{r_{i}}{n_{i}}
$$

Pengujian dilanjutkan dengan uji Mann-Whitney jika $H_{0}$ ditolak, dimana mother wavelet dengan $\bar{r}_{i}$ terendah dibandingkan dengan mother wavelet dengan $\bar{r}_{i}$ yang lain [11]. Tujuannya adalah untuk menentukan mother wavelet terbaik yaitu dengan menguji bahwa mother wavelet dengan $\bar{r}_{i}$ terendah dapat menghasilkan nilai MSE yang lebih kecil dari pada nilai MSE yang dihasilkan oleh mother wavelet yang lain. Dalam penelitian ini menggunakan 9 mother wavelet dan dengan demikian, jumlah perbandingan menggunakan uji Mann-Whitney adalah sebanyak 8 kali. Perumusan uji hipotesis untuk uji Mann-Whitney dalan penelitian ini dinyatakan oleh

$$
\begin{gathered}
H_{0}: X \text { dan } Y \text { memiliki nilai MSE yang sama } \\
H_{1}: \text { Nilai MSE untuk } X>\text { Nilai MSE untuk } Y
\end{gathered}
$$

dimana $Y$ menyatakan populasi untuk mother wavelet yang memiliki rata-rata peringkat nilai MSE terendah dan $X$ menyatakan populasi untuk mother wavelet yang lain. Statistik uji untuk uji Mann-Whitney yaitu

atau

$$
U_{1}=n_{1} n_{2}+\frac{n_{1}\left(n_{1}+1\right)}{2}-r_{1}
$$

$$
U_{2}=n_{1} n_{2}+\frac{n_{2}\left(n_{2}+1\right)}{2}-r_{2}
$$

dimana $n_{1}$ adalah ukuran sampel ke $-1, n_{2}$ adalah ukuran sampel ke-2 dan $r_{1}$ adalah jumlah peringkat dari sampel ke -1 dan $r_{2}$ adalah jumlah peringkat dari sampel ke -2 . Antara $U_{1}$ dan $U_{2}$ dipilih nilai yang lebih kecil untuk dijadikan $U_{H i t}$ atau $U$ yang akan dibandingkan dengan

Perbandingan Mother Wavelet dalam Proses Denoising pada Suara (Rahmat Ramadhan) 
$U_{\text {Tabel }}$ atau $U_{0}$. Misalkan $\alpha$ menyatakan tingkat signifikansi, maka wilayah kritik untuk penolakan $H_{0}$ berdasarkan perumusan uji hipotesis, yaitu terjadi ketika nilai $U \leq U_{0}$ dimana $P\left(U \leq U_{0}\right)=\alpha$. Nilai $U_{0}$ ditentukan dari Tabel Man-Whitney dengan asumsi bahwa $n_{1} \leq n_{2}$ dan $3 \leq n_{2} \leq 10$ [12].

Menurut [13], jika uji Mann-Whitney dilakukan sebanyak sekali dan menggunakan tingkat signifikansi sebesar $\alpha$, maka tingkat kepercayaan untuk sekali pengujian adalah $(1-\alpha)^{1} \%$. Dengan demikian, ketika pengujian dengan menggunakan tingkat signifikansi $\alpha$ dilakukan sebanyak 8 kali, maka tingkat kepercayaan untuk 8 kali hasil pengujian adalah sebesar $(1-\alpha)^{8} \%$.

Diketahui bahwa ketika $\alpha \neq 0$, maka nilai $(1-\alpha)<1$, sedemikian sehingga $(1-\alpha)^{k}<(1-\alpha) ; k>1$. Hal ini menunjukkan bahwa terjadi penurunan tingkat kepercayaan setelah dilakukan perbandingan sebanyak $k$ kali dimana $k>1$. Untuk mengatasi hal tersebut, maka dilakukan pengaturan nilai $\alpha$, dimana untuk setiap perbandingan menggunakan $\alpha_{*}=\frac{\alpha}{k}$, sehingga dengan melakukan $k$ kali perbandingan diperoleh tingkat kepercayaan sebesar $\left(1-\alpha_{*}\right)^{k}=1-\alpha$.

Dalam melakukan uji Mann-Whitney, digunakan tingkat signifikansi $\alpha=0,05$, sehingga untuk setiap perbadingan yang dilakukan, digunakan tingkat signifikansi $\alpha_{*}=\frac{\alpha}{k}=$ $\frac{0,05}{8}=0,00625$ dan dengan demikian, untuk $P\left(U \leq U_{0}\right)=0,00625$ maka nilai $U_{0}$ yang bersesuaian adalah $U_{0}=18$. Mother wavelet terbaik diperoleh bila untuk setiap perbandingan, hipotesis $H_{0}$ ditolak, jika tidak maka terdapat mother wavelet yang lain selain mother wavelet dengan $\bar{r}_{i}$ terendah yang dapat digunakan untuk proses denoising pada sinyal suara dan menghasilkan nilai MSE yang kecil.

Mother wavelet terbaik yang diperoleh untuk tiap jenis derau kemudian diterapkan untuk proses denoising pada sinyal suara berderau nyata. Untuk melakukan proses denoising pada suara berderau nyata, maka terlebih dahulu dilakukan penentuan jenis derau pada suara berderau nyata. Penentuan jenis derau WGN, WUN atau Colored Noise dilakukan dengan menunjukkan histogram untuk distribusi data derau yang direduksi dalam proses denoising dengan 4 level dekomposisi menggunakan mother wavelet yang beragam dari keluarga wavelet Daubechies, Coiflet dan Symlet. Histogram tersebut menentukan jenis distribusi derau sehingga dapat menentukan mother wavelet terbaik untuk suara berderau nyata. Jika distribusi data tidak mengikuti distribusi Gaussian ataupun distribusi Seragam, maka jenis deraunya termasuk Colored Noise, jika mengikuti distribusi Gaussian maka jenis derau adalah WGN dan mengikuti distribusi Seragam maka jenis derau adalah WUN.

Penentuan distribusi data derau yang tereduksi dilakukan dengan mengasumsikan bahwa suara berderau nyata $y(t) ; t=1,2, \ldots, n$ dapat dimodelkan seperti pada persamaan (16)

$$
y(t)=x(t)+n(t) ; t=1,2, \ldots, n
$$

dimana $x(t)$ menyatakan suara tanpa derau dan $n(t)$ menyatakan derau. Misalkan sinyal suara hasil denoising dinyatakan dengan $\hat{x}(t)$ maka

$$
\begin{gathered}
y(t)=\hat{x}(t)+n(t) \\
\leftrightarrow n(t)=y(t)-\hat{x}(t)
\end{gathered}
$$

Berdasarkan persamaan (17), $n(t)$ menyatakan derau yang direduksi ketika proses denoising dilakukan. Selanjutnya distribusi dari derau dapat ditunjukkan melalui $n(t)$ yang dihasilkan dari persamaan (17) [3].

\section{HASIL DAN PEMBAHASAN}

Rerata dan standar deviasi nilai MSE hasil denoising pada sinyal suara yang diberikan WGN ditunjukkan oleh Tabel 1.

IJCCS Vol. 8, No. 1, January 2014: 69-80 
Tabel 1 Rerata dan standar deviasi nilai MSE hasil denoising sinyal Suara_Asli yang diberikan WGN dengan 4 level dekomposisi

\begin{tabular}{|c|c|c|c|c|}
\hline Wavelet & $\begin{array}{c}\text { Level } \\
\text { Dekomposisi }\end{array}$ & Tipe Derau & Rerata MSE & $\begin{array}{c}\text { Standar } \\
\text { Deviasi MSE }\end{array}$ \\
\hline Db2 & 4 & WGN & 0,0017 & $1,3 \times 10^{-4}$ \\
\hline Db20 & 4 & WGN & 0,0013 & $9,72 \times 10^{-5}$ \\
\hline Db30 & 4 & WGN & 0,0014 & $1,58 \times 10^{-4}$ \\
\hline Db40 & 4 & WGN & 0,0014 & $1,43 \times 10^{-4}$ \\
\hline Coif3 & 4 & WGN & 0,0015 & $1,94 \times 10^{-4}$ \\
\hline Coif5 & 4 & WGN & 0,0015 & $1,75 \times 10^{-4}$ \\
\hline Sym4 & 4 & WGN & 0,0016 & $1,93 \times 10^{-4}$ \\
\hline Sym7 & 4 & WGN & 0,0015 & $1,97 \times 10^{-4}$ \\
\hline Sym8 & 4 & WGN & 0,0015 & $1,57 \times 10^{-4}$ \\
\hline
\end{tabular}

Untuk menguji kesamaan distribusi data nilai MSE yang dihasilkan oleh 9 populasi, maka dilakukan Uji Kruskal-Wallis terhadap 9 sampel. Berdasarkan hasil uji Kruskal-Wallis diperoleh nilai $h=32,54>\chi_{0,05}^{2}(8)=15,5 ; d f=8$. Dengan demikian $H_{0}$ ditolak sehingga dinyatakan bahwa terdapat perbedaan distribusi nilai MSE hasil denoising diantara mother wavelet untuk populasinya. Diperoleh pula bahwa Db20 memiliki rata-rata peringkat nilai MSE terendah yaitu $\bar{r}_{9}=17,90$. Uji Mann-Whitney kemudian dilanjutkan untuk menguji bahwa mother wavelet Db20 dapat menghasilkan nilai MSE terkecil dibandingkan dengan mother wavelet yang lain. Tabel 2 menunjukkan hasil uji Mann-Whitney untuk MSE hasil denoising pada suara yang diberikan derau WGN.

Tabel 2 Nilai $U$ hasil uji Mann-Whitney antara mother wavelet Db20 dengan mother wavelet yang lain untuk nilai MSE hasil denoising pada Suara Asli yang diberikan WGN

\begin{tabular}{|c|c|c|c|c|c|c|c|c|}
\hline & Db2 & Sym4 & Coif3 & Sym7 & Sym8 & Coif5 & Db30 & Db40 \\
\hline Db20 & 0,5 & 7,5 & 11,5 & 11 & 14 & 20 & 32 & 27,5 \\
\hline
\end{tabular}

Ket :

: Nilai MSE Db20 < Nilai MSE mother wavelet tertentu

: Nilai MSE Db20 = Nilai MSE mother wavelet tertentu

Dari uji Mann-Whitney diperoleh bahwa nilai MSE yang dihasilkan melalui proses denoising menggunakan mother wavelet Db20 adalah lebih kecil dibandingkan dengan nilai MSE yang dihasilkan oleh mother wavelet yang lain, kecuali terhadap Db40, Db30 dan Coif5. Dengan demikian diperoleh bahwa wavelet Db20, Db30, Db40 dan Coif5 dapat memberikan hasil denoising yang baik untuk proses denoising pada suara berderau WGN dengan memberikan nilai MSE yang kecil.

Tabel 3 menunjukkan rerata dan standar deviasi nilai MSE hasil denoising pada sinyal suara yang diberikan derau WUN. Selanjutnya untuk menguji kesamaan distribusi nilai MSE yang dihasilkan oleh 9 populasi, maka dilakukan uji Kruskal-Wallis terhadap 9 sampel. Berdasarkan hasil uji Kruskal-Wallis diperoleh nilai $h=61,95>\chi_{0,05}^{2}(8)=15,5 ; d f=8$. Dengan demikian $H_{0}$ ditolak sehingga dinyatakan bahwa terdapat perbedaan nilai MSE hasil denoising pada sinyal suara yang diberikan derau WUN untuk masing-masing mother wavelet yang digunakan. Diperoleh bahwa Db40 yang memiliki rata-rata peringkat nilai MSE terendah 
yaitu $\bar{r}_{9}=12,75$. Selanjutnya dilakukan uji Mann-Whitney dan hasil uji Mann-Whitney untuk MSE hasil denoising pada sinyal suara yang diberikan WUN ditunjukkan oleh Tabel 4.

Tabel 3 Rerata dan standar deviasi nilai MSE hasil denoising sinyal Suara_Asli yang diberikan WUN dengan 4 level dekomposisi

\begin{tabular}{|c|c|c|c|c|}
\hline Wavelet & $\begin{array}{c}\text { Level } \\
\text { Dekomposisi }\end{array}$ & Tipe Derau & Rerata MSE & $\begin{array}{c}\text { Standar } \\
\text { Deviasi MSE }\end{array}$ \\
\hline Db2 & 4 & WUN & 0,0034 & $9,69 \times 10^{-5}$ \\
\hline Db20 & 4 & WUN & 0,0025 & $1,52 \times 10^{-4}$ \\
\hline Db30 & 4 & WUN & 0,0025 & $1,42 \times 10^{-4}$ \\
\hline Db40 & 4 & WUN & 0,0024 & $6,84 \times 10^{-5}$ \\
\hline Coif3 & 4 & WUN & 0,0027 & $1,44 \times 10^{-4}$ \\
\hline Coif5 & 4 & WUN & 0,0025 & $1,29 \times 10^{-4}$ \\
\hline Sym4 & 4 & WUN & 0,0029 & $1,16 \times 10^{-4}$ \\
\hline Sym7 & 4 & WUN & 0,0026 & $1,47 \times 10^{-4}$ \\
\hline Sym8 & 4 & WUN & 0,0027 & $9,05 \times 10^{-5}$ \\
\hline
\end{tabular}

Tabel 4 Nilai $U$ hasil uji Mann-Whitney antara mother wavelet Db40 dengan mother wavelet yang lain untuk nilai MSE hasil denoising pada Suara Asli yang diberikan WUN

\begin{tabular}{|c|c|c|c|c|c|c|c|c|}
\hline & Db2 & Sym4 & Coif3 & Sym8 & Sym7 & Coif5 & Db20 & Db30 \\
\hline Db40 & 0 & 0 & 0,5 & 0 & 5,5 & 18 & 25 & 23,5 \\
\hline
\end{tabular}

Ket :

: Nilai MSE Db40 < Nilai MSE mother wavelet tertentu

: Nilai MSE Db40 = Nilai MSE mother wavelet tertentu

Berdasarkan hasil uji Mann-Whitney diperoleh bahwa nilai MSE yang dihasilkan melalui proses denoising menggunakan mother wavelet $\mathrm{Db} 40$ adalah lebih kecil dibandingkan dengan nilai MSE yang dihasilkan oleh mother wavelet yang lain, kecuali terhadap Db20 dan Db30. Diperoleh bahwa wavelet Db40, Db30 dan Db20 dapat memberikan hasil denoising yang baik untuk proses denoising pada suara berderau WUN dengan memberikan nilai MSE yang kecil.

Rerata dan standar deviasi nilai MSE hasil denoising pada sinyal suara yang diberikan derau Colored Noise ditunjukkan oleh Tabel 5. Selanjutnya untuk pengujian terhadap kesamaan distribusi nilai MSE yang dihasilkan oleh 9 populasi dapat dilakukan dengan menggunkan uji Kruskal-Wallis terhadap 9 sampel. Berdasarkan hasil uji Kruskal-Wallis diperoleh nilai $h=25,85>\chi_{0,05}^{2}(8)=15,5 ; d f=8$. Dengan demikian $H_{0}$ ditolak sehingga dinyatakan bahwa terdapat perbedaan distribusi nilai MSE yang dihasilkan dalam denoising pada sinyal suara yang diberikan derau Colored Noise untuk masing-masing mother wavelet. Diperoleh bahwa Sym7 memperoleh rata-rata peringkat terendah yaitu $\bar{r}_{9}=31$. Selanjutnya dilakukan uji Mann-Whitney dan Tabel 6 menunjukkan hasil uji Mann-Whitney.

Diketahui bahwa Db2 memiliki rata-rata nilai MSE terkecil namun setelah dilakukan uji Kruskal-Wallis, diperoleh bahwa Sym7 memiliki peringkat terendah yaitu $\bar{r}_{9}=30,70$. Hal ini menunjukkan bahwa nilai-nilai MSE yang dihasilkan dalam proses denoising menggunakan Sym7 adalah lebih kecil dibandingkan dengan yang dihasilkan menggunakan Db2 meskipun hasil denoising dengan menggunakan Db2 memberikan rata-rata nilai MSE terkecil. Diperoleh pula bahwa nilai MSE sinyal suara hasil denoising yang diperoleh menggunakan Sym7 adalah

IJCCS Vol. 8, No. 1, January 2014: 69-80 
lebih kecil hanya terhadap Db30 dan Db40, sehingga diperoleh bahwa selain wavelet Db30 dan Db40, mother wavelet yang lain yang digunakan dalam penelitian ini dapat memberikan hasil denoising yang baik untuk proses denoising pada suara berderau Colored Noise, dengan memberikan nilai MSE yang kecil.

Tabel 5 Rerata dan standar deviasi nilai MSE hasil denoising sinyal Suara Asli yang diberikan Colored Noise dengan 5 level dekomposisi

\begin{tabular}{|c|c|c|c|c|}
\hline Wavelet & $\begin{array}{c}\text { Level } \\
\text { Dekomposisi }\end{array}$ & Tipe Derau & Rerata MSE & $\begin{array}{c}\text { Standar } \\
\text { Deviasi MSE }\end{array}$ \\
\hline Db2 & 5 & Colored & 0,0112 & 0,019 \\
\hline Db20 & 5 & Colored & 0,0405 & 0,045 \\
\hline Db30 & 5 & Colored & 0,0689 & 0,055 \\
\hline Db40 & 5 & Colored & 0,0967 & 0,062 \\
\hline Coif3 & 5 & Colored & 0,0176 & 0,030 \\
\hline Coif5 & 5 & Colored & 0,0328 & 0,036 \\
\hline Sym4 & 5 & Colored & 0,0124 & 0,020 \\
\hline Sym7 & 5 & Colored & 0,0142 & 0,021 \\
\hline Sym8 & 5 & Colored & 0,0148 & 0,024 \\
\hline
\end{tabular}

Tabel 6 Nilai $U$ hasil uji Mann-Whitney antara mother wavelet Sym7 dengan mother wavelet yang lain untuk nilai MSE hasil denoising pada Suara Asli yang diberikan Colored Noise

\begin{tabular}{|c|c|c|c|c|c|c|c|c|}
\hline & Db40 & Db30 & Db20 & Coif5 & Db2 & Sym4 & Coif3 & Sym8 \\
\hline Sym7 & 9 & 16 & 31,5 & 36,5 & 34 & 35,5 & 45 & 44,5 \\
\hline
\end{tabular}

Ket :

: Nilai MSE Sym7 < Nilai MSE mother wavelet tertentu

: Nilai MSE Sym7 = Nilai MSE mother wavelet tertentu

Hasil denoising menggunakan Db20 pada sinyal suara yang diberikan WGN adalah seperti pada Gambar 2.
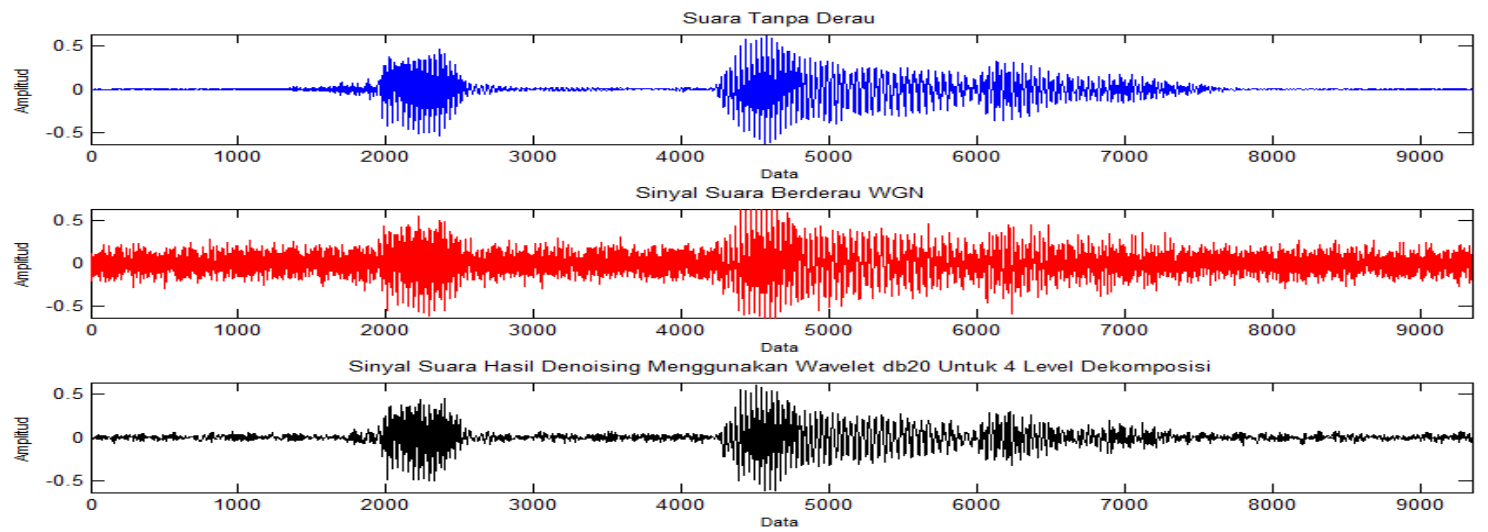

Gambar 2 Sinyal Suara_Asli hasil denoising (bawah) menggunakan mother wavelet Db20

Hasil denoising menggunakan Db40 pada sinyal suara yang diberikan WUN adalah seperti pada Gambar 3.

Perbandingan Mother Wavelet dalam Proses Denoising pada Suara (Rahmat Ramadhan) 

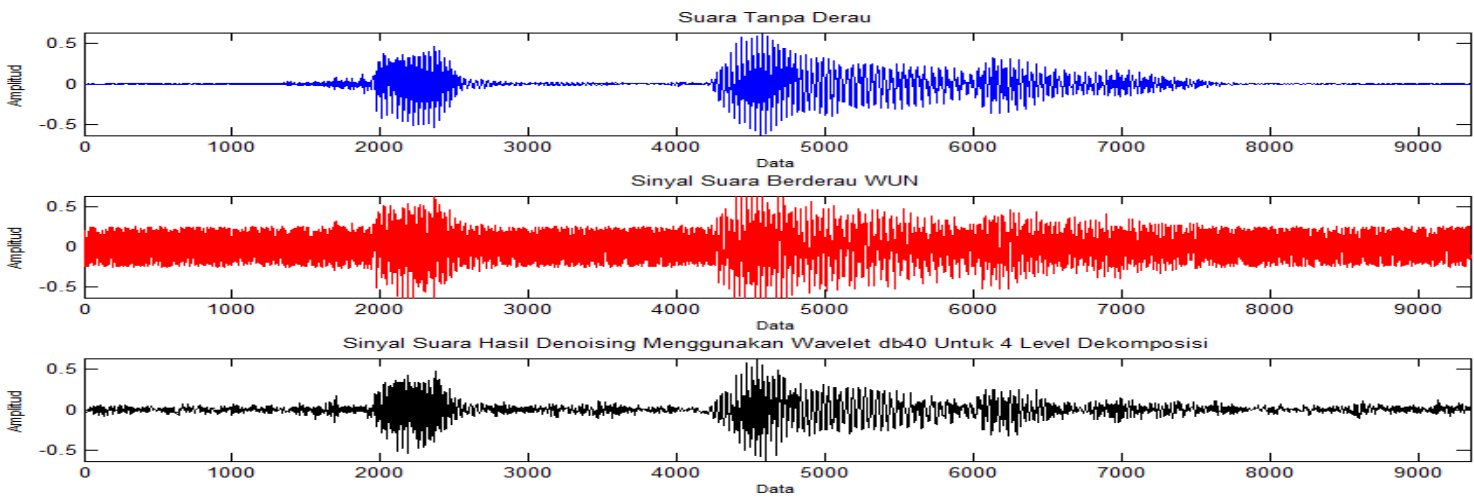

Gambar 3 Sinyal Suara_Asli hasil denoising (bawah) menggunakan mother wavelet Db40

Hasil denoising menggunakan Sym7 pada sinyal suara yang diberikan Colored Noise adalah seperti pada Gambar 4.
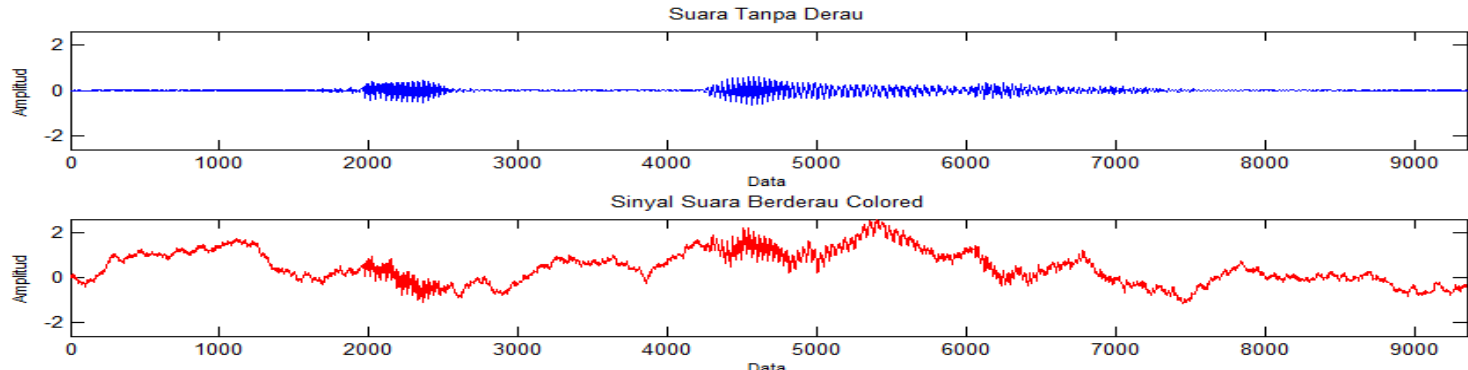

Sinyal Suara Hasil Denoising Menggunakan Wavelet sym7 Untuk 5 Level Dekomposisi

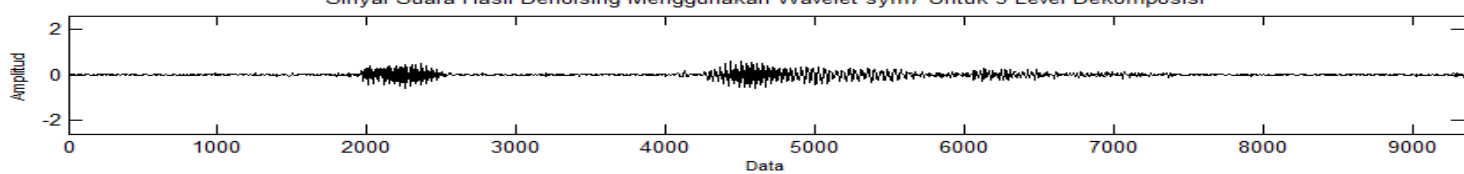

Gambar 4 Sinyal Suara_Asli hasil denoising (bawah) menggunakan mother wavelet Sym7

Setelah dilakukan pengecekan jenis derau pada sinyal suara berderau nyata, diperoleh bahwa seluruh sinyal suara nyata yang digunakan mengandung derau WGN. Dengan demikian untuk proses denoising dapat digunakan mother wavelet Db20, Db30, Db40 dan Coif5. Hasil denoising pada sinyal suara berderau nyata dari potongan rekaman cockpit Adam Air (sinyal Adm1) misalnya menggunakan Db20 adalah seperti pada Gambar 5.
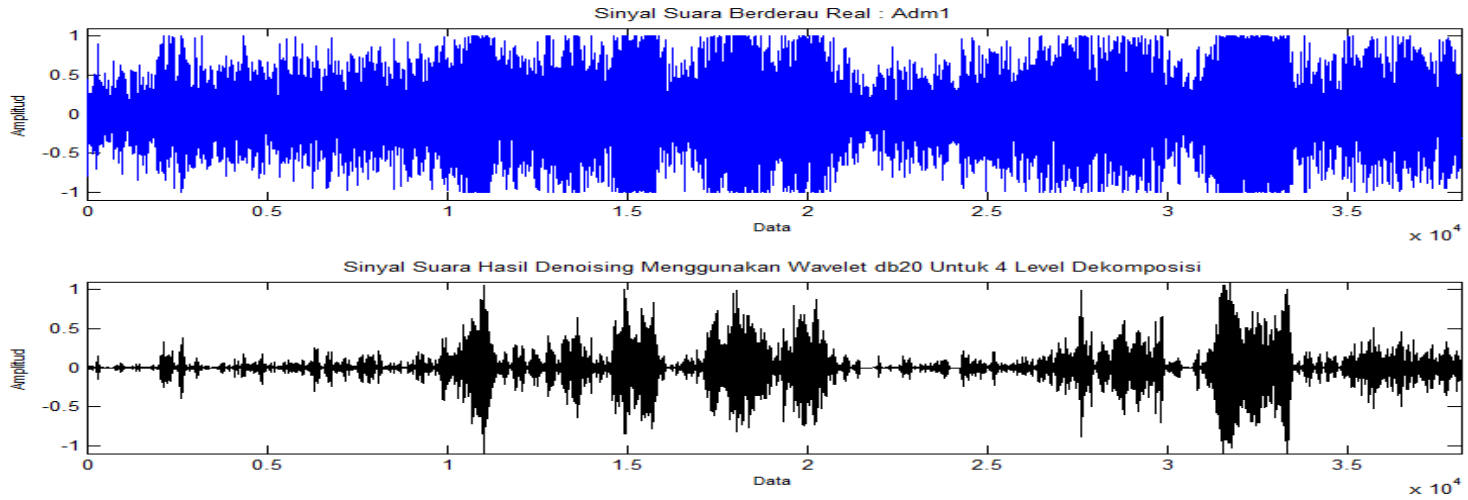

Gambar 5 Sinyal Adm1 hasil denoising (bawah) menggunakan mother wavelet Db20

Diketahui bahwa suatu fungsi wavelet $\psi(x)$ dengan $M$ vanishing moment dari suatu mother wavelet dapat memberikan nilai korelasi yang kecil (mendekati nol) atau bahkan memberikan nilai korelasi yang sama dengan nol (tidak berkorelasi) terhadap suatu sinyal polinomial $a(x)=\sum_{m=0}^{M-1} b_{m} x^{m}$ berderajat maksimal $M-1$. Hal ini menunjukkan bahwa 
ketika $\psi(x)$ digunakan untuk menganalisis $a(x)$ akan menghasilkan nilai koefisien Detil yang sama dengan atau mendekati nol. Nilai koefisien Detil yang demikian menunjukkan bahwa sinyal $a(x)$ ditahan/tidak dilewatkan pada subband koefisien Detil.

Berdasarkan hasil penelitian, sinyal suara yang diberikan WGN dan WUN memerlukan mother wavelet dengan jumlah vanishing moment yang besar untuk $\psi(x)$ untuk memberikan hasil yang baik dalam proses denoising. Untuk sinyal suara berderau WGN dibutuhkan jumlah vanishing moment minimal sebesar 10 dan mother wavelet yang memenuhi adalah Db20, Db30, Db40 dan Coif5 yang masing-masing memiliki 20, 30, 40 dan 10 vanishing moment. Untuk sinyal suara yang diberikan derau WUN, diperoleh mother wavelet yang baik untuk melakukan proses denoising pada sinyal suara yaitu Db40, Db20 dan Db30. yang masingmasing memiliki 40, 20 dan 30 vanishing moment.

Jumlah vanishing moment yang demikian dibutuhkan karena pada sinyal suara yang diberikan derau WGN ataupun WUN dilakukan ekstraksi derau dengan harapan bahwa pada subband Detil dapat dilewatkan bagian derau sebanyak mungkin sehingga ketika proses thresholding dilakukan, bagian derau tersebut dapat dihilangkan.

Hal berbeda diperoleh untuk sinyal suara berderau Colored Noise yang ternyata membutuhkan mother wavelet dengan jumlah vanishing moment yang lebih sedikit dibandingkan dengan yang dibutuhkan untuk sinyal suara berderau WUN atau WGN. Diperoleh bahwa jumlah vanishing moment yang dibutuhkan adalah maksimal sebanyak 20 yaitu untuk mother wavelet Db20. Diketahui bahwa sinyal Colored Noise dapat diasumsikan sebagai sebuah sinyal halus berfrekuensi rendah yang diberikan sinyal gangguan berfrekuensi tinggi, sehingga dengan jumlah vanishing moment yang sedikit memungkinkan terjadinya korelasi antara bagian suara dan bagian sinyal Colored Noise berfrekuensi tinggi terhadap $\psi(x)$ pada leve-level awal dekomposisi. Hal ini diharapkan karena tujuan dari ekstraksi sinyal adalah melewatkan sebanyak mungkin bagian sinyal pada subband Detil.

Jumlah vanishing moment yang sedikit ini juga dapat mengaproksimasi bentuk sinyal suara yang berfrekuensi rendah pada dekomposisi level 5, sehingga dapat melewatkannya pada suband koefisien Detil 5 dan menyisakan bagian derau Colored Noise pada subband koefisien Aproksimasi 5. Bagian frekuensi dari derau yang tersisa pada subband koefisien Aproksimasi 5 menunjukkan bahwa jumlah vanishing moment yang digunakan menyebabkan nilai korelasi antara $\psi(x)$ dengan bagian frekuensi rendah sinyal Colored Noise adalah nol sehingga seluruh bagian derau tersebut tidak dilewatkan pada subband koefisien Detil 5, tetapi dilewatkan pada subband koefisien Aproksimasi 5 dan pada saat proses thresholding dilakukan, bagian derau tersebut dapat direduksi untuk menghilangkan pengaruh Colored Noise dalam sinyal suara.

\section{KESIMPULAN}

Mother wavelet terbaik yang dapat digunakan dalam proses denoising pada suara yang diberikan derau White Gaussian Noise (WGN) adalah Db20, Db30, Db40dan Coif5; White Uniform Noise (WUN) adalah Db40, Db30 dan Db20 serta untuk Colored Noise terdapat beberapa mother wavelet selain Db30 dan Db40, yang digunakan dalam penelitian ini yang dapat digunakan untuk mereduksi derau Colored Noise. Untuk penerapan pada sinyal suara berderau nyata, diperoleh bahwa jenis derau yang terkandung adalah berjenis WGN, sehingga digunakan mother wavelet Db20, Db30, Db40 atau Coif5 untuk melakukan proses denoising dengan harapan dapat memberikan nilai MSE yang kecil.

\section{SARAN}

Diketahui bahwa dalam penelitian yang dilakukan masih terdapat kekurangan yang memerlukan penelitian yang lebih lanjut guna menghasilkan hasil penelitian yang lebih baik

Perbandingan Mother Wavelet dalam Proses Denoising pada Suara (Rahmat Ramadhan) 
lagi. Oleh karena itu untuk penelitian selanjutnya dapat menggunakan wavelet terbaik yang diperoleh dalam penelitian ini untuk proses denoising pada suara dan dapat memodifikasi atau menggunakan teknik penentuan nilai threshold yang lain. Penelitian ini dapat pula dilanjutkan dengan menerapkan proses denoising menggunakan wavelet terbaik sebagai tahap preprocessing dalam melakukan pengenalan suara pada lingkungan yang mengandung derau.

\section{DAFTAR PUSTAKA}

[1] Kumar, P. dan Foufoula-Georgiou, E., 1994, Wavelet Analysis in Geophysics : An Introduction, Wavelet in Geophysic, Academic Press Inc, USA.

[2] Fugal, D. L., 2009, Conceptual Wavelets in Digital Signal Processing, Space and Sinyal Technical Publishing, Sandiego, California.

[3] Balakrishnan, V., Borges, N. dan Parchmen, L., 2006, Wavelet Denoising and Speech Enhancement, www.nashborges.com/research/speech enhancementpaper.pdf, diakses 23 September 2012.

[4] Sheikhzadeh, H. dan Abutalebi, H.R., 2001, An Improved Wavelet Based Speech Enhancement System, www.onsemi.com/site/pdf/Eurospeech 2001_Wavel.pdf, diakses 23 September 2012.

[5] Fu, Q. Dan Wan, E.A., 2003, A Novel Speech Enhancement System Based on Wavelet Denoising, speech.bme.ogi.edu/publications/ps/fu03.pdf, diakses 23 September 2012.

[6] Bahgat, S. F. dan Fayed, Z. T., 2004, Wavelet Based Speech Enhancement using Nonlinear Envelope Expansion Method, International Journal of Intelligent Computing And Information Sciences, Faculty of Computer \& Information Sciences, Ain Shams University, Cairo, Egypt.

[7] Li, N. dan Zhao, M., 2008, Audio Denoising Algorithm Based on Adaptive Wavelet Soft Thresholding of Gain Factor and Teager Energy Operator, Proceedings of IEEE International Conference on Computer Science and Software Engineering, 1, 787-790.

[8] Chen, S. dan Wang, J., 2004, Speech Enhancement Using Perceptual Wavelet Packet Decomposition and Teager Energy Operator, Journal of VLSI Signal Processing, 32, $125-139$.

[9] Bahoura, M. dan Routa, J., 2001, Wavelet Speech Enhancement Based on The Teager Energy Operator, IEEE Signal Processing Letters, 8,1,10-12.

[10] Walpole, R., E., 1992, Pengantar Statistika, edisi 3, (diterjemahkan oleh : Sumantri, B), PT. Gramedia Pustaka Utama, Jakarta.

[11] Ramachandran, K.,M. dan Tsokos, C., P., 2009, Mathematical Statistics with Application, Academic Press, USA.

[12] Wackerly, D., D., Mendenhall, W. dan Scheaffer, R., L., 2008, Mathematical Statistics with Application, Thomson Brooks/Cole, USA.

[13] McClave, J. T. dan Sincich, T, 2000, Statistics, Prentice Hall, New Jersey.

IJCCS Vol. 8, No. 1, January 2014: 69-80 